\title{
PENGARUH PENGGUNAAN BEBERAPA JENIS MEDIA FILTRASI TERHADAP KUALITAS LIMBAH CAIR EKSTRAKSI SAGU
}

\author{
Sarman Oktovianus Gultom ${ }^{1 *}$, Trhessya N. Mess ${ }^{1}$, Isak Silamba ${ }^{1}$ \\ ${ }^{1}$ Teknologi Hasil Pertanian, Fakultas Teknologi Pertanian, Universitas Papua \\ Email: sarmangultom82@gmail.com
}

\begin{abstract}
Sago is a carbohydrate-producing plant that is widely found in Papua. The main product of sago plant processing is sago starch which in the extraction process is carried out with the help of water media. Water that has been used in the extraction process of sago starch is generally only disposed of as waste that is not useful, even potentially polluting the environment. Therefore, to improve the quality of liquid waste, filtration needs to be carried out. This study aims to see the effect of several types of filtration media on the quality of sago extraction wastewater. In this study three types of filtration media were used, namely sand (P), coconut fiber $(S)$ and coconut shell charcoal $(A)$ and a combination of sand and coconut fiber (PS), sand and coconut shell charcoal (PA), coconut fibers and charcoal coconut shell (SA). The parameters of the quality of the sago extraction wastewater were observed in total suspended solids (TSS), total dissolved solids (TDS), pH, temperature, odor, and color. The results showed that coconut shell charcoal filtration media was better than the other two types in decreasing TSS and TDS by $17 \%$ and $24 \%$ respectively. However, if the filtration media was combined, it will produce a better quality of wastewater compared to a single filtration medium (without combination) for all observation parameters. An increase in $\mathrm{pH}$ and odorless happened for the wastewater after filtration in all treatments
\end{abstract}

Keywords: filtration, filtration media, wastewater, sago, extraction

\section{PENDAHULUAN}

Sagu (Metroxylon) merupakan sumber alam kaya karbohidrat yang banyak tersebar di Indonesia khususnya di wilayah Papua. Sebanyak 1.128 juta Ha sagu tumbuh di Indonesia atau sebanyak $50 \%$ tanaman sagu dunia, dan $90 \%$ dari jumlah tersebut berkembang di wilayah Papua dan Maluku (Flach 1983, Lakuy \& Limbongan 2003, Limbongan 2007). Bagi masyarakat Papua, tanaman sagu dimanfaatkan untuk menghasilkan pati sagu sebagai bahan utama pembuatan berbagai jenis makanan tradisional seperti papeda, sagu bakar, dan lainnya. Secara tradisional pengolahan tananam sagu untuk menghasilkan pati harus melalui beberapa tahapan antara lain penebangan batang sagu, pembersihan, penokokan dan ekstraksi. Proses ekstraksi dimaksudkan untuk mengeluarkan pati sagu dari empulur batang sagu dengan bantuan media air. Umumnya pengolahan sagu dilakukan dekat sumber air seperti di pinggiran sungai ataupun anak sungai (Haryanto \& Siswari 2004).

Haryanto dan Siswari (2004) juga menjelaskan bahwa pada proses pengolahan sagu, selain pati sebagai produk utama yang dihasilkan, juga dihasilkan berbagai limbah berupa kulit batang sagu, residu empelur sagu berserat (ampas), dan air limbah hasil ekstraksi sagu. Limbah pada dasarnya merupakan suatu bahan yang terbuang atau dibuang dari suatu sumber hasil aktifitas manusia maupun proses-proses alam yang tidak atau belum mempunyai nilai ekonomis. 
Pada umum, proses pengolahan sagu yang dilakukan secara tradisional membutuhkan air yang sangat banyak, yaitu sekitar 21 liter per kilogram empulur sagu, yang bertujuan untuk memisahkan pati sagu dari empulurnya, terutama pada proses ekstraksi (Tumbel 2014). Oleh sebab itu, kegiatan pengolahan sagu pada umumnya dilakukan di sekitar sungai atau perairan sehingga mudah untuk dilakukan kegiatan ekstraksi pati sagu. Pada proses ekstraksi ini, air yang telah digunakan umumnya dibuang ke sungai sekitar tempat proses ekstraksi dilakukan sebagai limbah. Hasil penelitian Kusuma, et al. (2012) menyatakan bahwa limbah cair dari proses ekstraksi sagu dapat menyebabkan kandungan oksigen terlarut di dalam air menjadi rendah bahkan habis sama sekali dengan beban organik sebesar $10,4 \mathrm{~kg}$ $\mathrm{COD} / \mathrm{m} 3$ hari. Berdasarkan studi yang dilakukan oleh Phang, et al. (2000), pada skala industri, limbah cair sagu biasanya dibuang ke sungai sebanyak 10-22 ton per hari. Limbah cair sagu yang dihasilkan memiliki kandungan organik yang tinggi dengan rasio karbon: nitrogen sebesar 105 : 0,12. Jika limbah cair ini dibuang ke perairan, maka akan terjadinya pembusukan pada permukaan air, akibatnya akan menghambat kontak antara air dan udara bebas sekitarnya yang akan mempengaruhi kehidupan biota di perairan tersebut (Ahmad 1992, Awg-Adeni et al. 2010)

Pengolahan limbah cair hasil ekstraksi pati sagu tersebut perlu dilakukan perlakuan penduluan, khususnya pengurangan padatan yang terkandung dalam limbah cair, sebelum dialirkan ke sungai atau perairan sekitar tempat pengolahan. Hal ini dimaksudkan untuk meminimal dampak negatif ditimbulkan terhadap lingkungan sekitar, seperti terjadinya pembusukan ataupun polusi bau yang disebabkan oleh penguraian bahan organik. Salah satu metode pengelolaan limbah cair sagu adalah metode filtrasi.

Pada umumnya proses filtrasi digunakan untuk melakukan penjernihan air. Media filtrasi yang umum digunakan pada proses penjernihan air tersebut adalah pasir, serabut kelapa dan arang tempurung kelapa. Ketiga media filtrasi tersebut diduga memiliki pengaruh terhadapa kualitas limbah cair ekstraksi sagu. Oleh sebab itu, pada penelitian ini, ketiga media filtrasi tersebut akan dicobakan untuk mengetahui pengaruhnya terhadap kualitas limbah cair ekstraksi sagu.

\section{BAHAN DAN METODE}

Penelitian ini dilaksanakan di Laboratorium Teknologi Pertanian Universitas Papua. Bahan utama yang diperlukan untuk penelitian ini adalah limbah cair hasil ekstraksi sagu serta tiga jenis media filtrasi, yaitu serabut kelapa, arang tempurung kelapa dan pasir. Peralatan yang digunakan yaitu jerigen plastik berkapasitas 5 liter, kran, kain, pompa vakum, Kompor listrik, $\mathrm{pH}$ meter, cawan almunium, autoclave, cell counter, timbangan analitik, oven, inkubator dan peralatan gelas untuk analisis.

Penelitian ini menggunakan Rancangan Acak Lengkap (RAL) dengan 7 perlakuan media filtrasi. Pengulangan dilakukan sebanyak 3 kali untuk masingmasing pengulangan (Tabel 1). 
Tabel 1. Perlakuan Media Filtrasi

\begin{tabular}{lcc}
\hline \multicolumn{1}{c}{ Media filtrasi } & Simbol & Total ketebalan \\
\hline Pasir & P & $5 \mathrm{~cm}$ \\
Serabut kelapa & S & $5 \mathrm{~cm}$ \\
Arang tempurung kelapa & A & $5 \mathrm{~cm}$ \\
Pasir + Serabut kelapa & PS & $10 \mathrm{~cm}$ \\
Pasir + Arang tempurung kelapa & PA & $10 \mathrm{~cm}$ \\
Serabut kelapa + Arang tempurung kelapa & SA & $10 \mathrm{~cm}$ \\
\hline
\end{tabular}

Ket: ketebalan masing-masing media $5 \mathrm{~cm}$

\section{Tahapan penelitian}

1. Persiapan Sampel Limbah Cair

Pohon sagu yang telah berusia panen ditebang dan dibersihkan dari pelepah dan kulitnya hingga diperoleh empulur yang telah bersih. Empulur tersebut kemudiaan diparut menggunakan mesin parut sagu hingga menghasilkan parutan empulur sagu. Parutan empulur sagu tersebut kemudian diperas dengan bantuan air hingga mengasilkan campuran air dan pati sagu yang dilewatkan pada kain saring. Campuran air dan pati sagu biarkan selama 1 malam hingga seluruh pati sagu mengendap. Air pada campuran tersebut kemudian dipisahkan dari endapan pati sagu untuk kemudian digunakan sebagai bahan penelitian yang akan disaring pada beberap media filtrasi.

2. Persiapan Media Filtrasi

Wadah filtrasi limbah cair ekstraksi sagu dibuat dengan menggunakan jerigen plastik dengan kapasitas 5 liter. Pada bagian bawah wadah dibuat lubang kecil yang telah diberi kran untuk pengeluaran limbah cair yang telah melalui media filtrasi. Bagian dalam wadah jerigen diisi dengan media filtrasi sesuai dengan perlakuan pada Tabel 1 .

3. Pengujian Kualitas Limbah Cair

Kualitas limbah cair hasil ekstraksi pati sagu diuji sebelum dan sesudah difilter pada beberapa media filtrasi. Hal ini dilakukan untuk melihat seberapa besar pengaruh jenis media filtrasi terhadap kualitas limbah cair yang dihasilkan.

\section{Variabel Pengamatan \\ Padatan Tersuspensi}

Pengukuran padatan tersuspensi menggunakan metode gravimetri SNI 066989.3-2004 (BSN 2004). Sampel dikocok hingga homogen dan dipipet sebanyak 50 $\mathrm{ml}$ lalu disaring menggunakan kertas saring yang sudah dikeringkan dengan bantuan pompa vakum. Setelah itu, kertas saring yang telah mengandung padatan tersebut keringkan dalam oven pada suhu 105 OC selama 1 jam kemudian didingikan dalam desikator lalu ditimbang hingga konstan. Padatan tersuspensi dihitung dengan menggunakan rumus:

$$
\text { Total Padatan Tersuspensi }=\frac{\left(\begin{array}{ll}
A & B
\end{array}\right) 1.000 .000}{a}(\mathrm{mg} / \mathrm{L})
$$

dimana:

$\mathrm{A}=$ Berat tetap kertas saring + residu $(\mathrm{g})$

$\mathrm{B}=$ Berat kertas saring kosong $(\mathrm{g})$

$\mathrm{a}=$ Volume sampel $(\mathrm{ml})$

\section{Padatan Terlarut}

Pengukuran padatan terlarut didasarkan pada SNI 06-6989.27-2005 (BSN 2005). Sampel limbah ekstraksi sagu dikocok hingga homogen dan dipipet sebanyak $50 \mathrm{~mL}$ dan dilakukan filtrasi menggunakan kertas saring. Sampel yang lolos dari kertas saring dituang ke dalam cawan allumunium. Selanjutnya, cawan yang berisi sampel tersebut diuapkan dan dikeringkan dalam oven pada suhu $105 \mathrm{oC}$ 
sampai semua air menguap. Setelah itu, cawan dikeluarkan dari oven menggunakan penjepit cawan untuk didinginkan dalam desikator dan ditimbang segera dengan neraca analitik hingga diperoleh berat konstan. Total Padatan Terlarut dihitung dengan persamaan berikut :

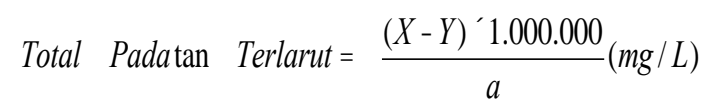

dimana:

$\mathrm{X}=$ Berat tetap cawan + Residu $(\mathrm{g})$

$\mathrm{Y}=$ Berat cawan kosong $(\mathrm{g})$

$\mathrm{a}=\operatorname{Volume}$ sampel $(\mathrm{ml})$

$p H$

Pengukuran $\mathrm{pH}$ mengacu pada SNI 06-6989.11-2004 (BSN 2004). Sampel dimasukkan pada gelas kimia lalu $\mathrm{pH}$ diukur menggunakan alat $\mathrm{pH}$ meter yang tekah dikalibrasi.

\section{Warna dan Bau}

Pengujian warna dan bau limbah cair ekstraksi sagu dilakukan berdasarkan penginderaan manusia mengacu pada SNI 06-6989.25-2005 (BSN 2005). Sampel limbah cair sebelum dan sesudah filtrasi dimasukan ke dalam erlenmeyer dan diamati perbandingan warnanya secara visual. Pengujian bau limbah cair ekstraksi sagu dilakukan dengan cara sampel dimasukan ke dalam sebuah botol tertutup (setengah), botol berisi sampel kemudian dikocok dengan kuat dan tutup botol dibuka dan aroma/bau dari sampel dibaui melalui mulut botol.

\section{Analisis Data}

Data yang diperoleh disajikan dalam bentuk grafik dan tabel serta dianalisis secara deskriptif.

\section{HASIL DAN PEMBAHASAN Total Padatan Tersuspensi}

Padatan tersuspensi merupakan padatan melayang dalam cairan limbah.
Pengaruh total padatan tersuspensi lebih nyata dibandingkan dengan padatan terlarut. Padatan tersuspensi mempengaruhi kekeruhan dan warna air. Apabila terjadi pengendapan dan pembusukan zat-zat tersebut di badan air penerima, maka air buangan akan mengurangi nilai guna perairan tersebut (Jenie \& Rahayu 1993). Hasil pengamatan padatan tersuspensi sebelum filtrasi dan sesudah filtrasi dengan perlakuan media filtrasi ditunjukkan pada Gambar 1.

Efektifitas penurunan padatan tersuspensi yaitu berkisar antara 8-17\%. Media filtrasi arang terlihat lebih efektif dalam menurunkan nilai total padatan tersuspensi dibanding dengan kedua media lainnya. Efektifitas penurunan pada media arang (perlakuan A) sebesar 17\%. Hal ini diduga disebabkan karena arang tempurung kelapa mengandung karbon yang dapat berfungsi sebagai adsorben, sehingga permukaan arang lebih menyerap zat-zat yang akan dihilangkan termasuk padatan tersuspensi (Atyani et al. 2014).

Limbah cair ekstraksi sagu yang diberi perlakuan media kombinasi terlihat lebih efektif dibanding media filtrasi tanpa kombinasi. Perlakuan kombinasi media filtrasi (PS, PA dan SA) terlihat lebih baik dalam menurunkan nilai total padatan tersuspensi jika dibandingkan dengan media filtrasi tanpa kombinasi. Nilai padatan tersuspensi sebelum filtrasi yaitu $168 \mathrm{mg} / \mathrm{L}$ namun setelah diberi perlakuan kombinasi media filtrasi (PS, PA, SA) nilai padatan tersuspensi berkisar antara 86-96 $\mathrm{mg} / \mathrm{L}$ dengan efektifitas penurunannya berkisar 43-49\%. Perlakuan PA terlihat lebih efektif dibanding perlakuan PS dan SA. Selain arang sebagai penyerap, pasir juga diduga dapat menyerap padatan tersuspensi dalam limbah cair ekstraksi sagu. Utami (2013) menyatakan bahwa bahan pencemar dalam limbah cair akan bertumbukan dan terserap kedalam partikel-partikel pasir. 


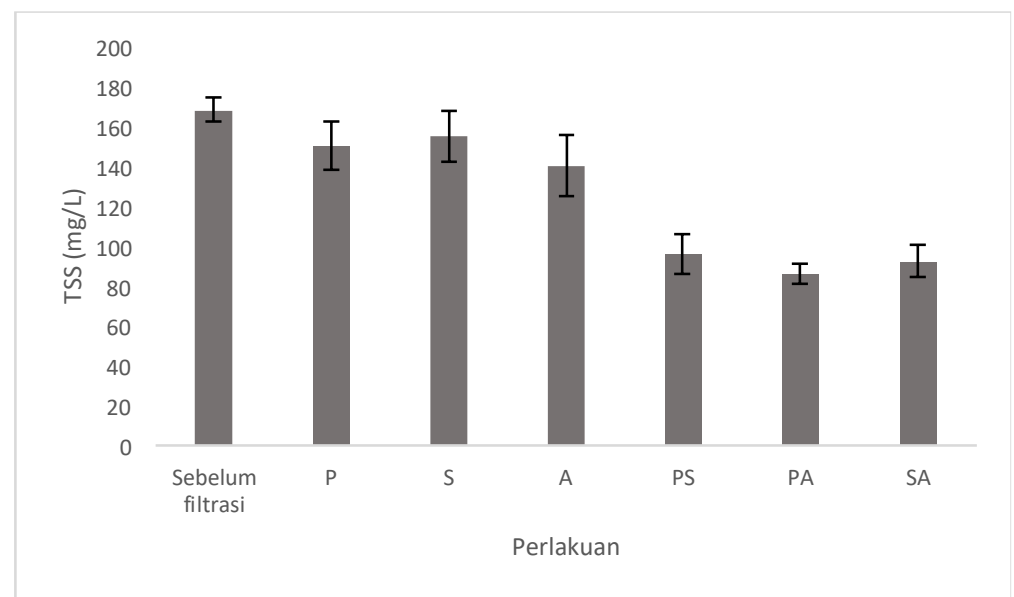

Gambar 1. Total Padatan Tersuspensi (mg/L) Sebelum dan Sesudah Filtrasi

\section{Total Padatan Terlarut}

Padatan terlarut merupakan padatan yang terdapat dalam filtrat yang diperoleh setelah penghilangan padatan tersuspensi. Padatan ini mewakili garamgaram dalam larutan, termasuk garamgaram mineral dari penyediaan air. Padatan terlarut ini penting terutama apabila limbah cair akan digunakan kembali setelah pengolahan, padatan terlarut merupakan parameter dari jumlah material yang dilarutkan dalam air (Siwardi \& Putra 2014). Hasil pengamatan penurunan nilai total padatan terlarut sebelum dan sesudah filtrasi pada media filtrasi dapat dilihat pada Gambar 2.

Gambar 2 menunjukkan bahwa nilai total padatan terlarut sebelum filtrasi yaitu $8472 \mathrm{mg} / \mathrm{L}$ namun setelah diberi perlakuan $\mathrm{P}, \mathrm{S}$ dan A nilai TDS limbah cair ekstraksi sagu berkisar antara 6429-6578 mg/L dengan efektifitas penurunan berkisar antara 22-24\%. Media arang terlihat lebih efektif dibanding kedua media lainnya yaitu $24 \%$. Arang tempurung kelapa diduga dapat menyerap komponen- komponen yang terlarut dalam limbah cair karena adanya perbedaan muatan antara permukaan karbon dan bahan yang diserap.

Limbah cair ekstraksi sagu yang diberi perlakuan media kombinasi terlihat lebih efektif dibanding media filtrasi tanpa kombinasi. Limbah cair ekstraksi sagu yang disaring dengan kombinasi media filtrasi yaitu perlakuan PS, PA dan SA terlihat lebih efektif dalam menurunkan nilai total padatan terlarut dibandingkan dengan tanpa kombinasi. Nilai total padatan terlarut limbah cair ekstraksi sagu pada perlakuan PA yaitu $26,3 \%$ terlihat lebih efektif jika dibandingkan dengan perlakuan PS dan SA. Selain arang, pasir juga memiliki peranan yang penting dalam menurunkan konsentrasi total padatan terlarut. Susilawaty et al. (2007) melaporkan bahwa pasir merupakan tempat tumbuh dan hidupnya mikrooganisme yang akan membantu proses penurunan kandungan pencemar dengan memakan zat-zat organik yang terkandung pada air limbah pada saat air limbah melewati pasir penyaring. 


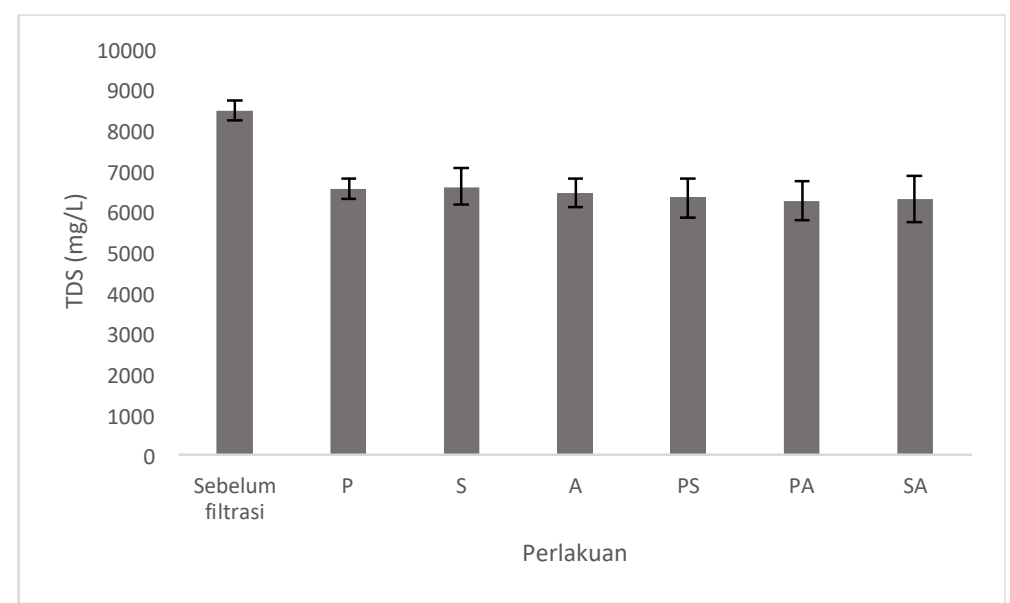

Gambar 2. Total Padatan Terlarut (mg/L) Sebelum dan Sesudah Filtrasi

pH

$\mathrm{pH}$ adalah istilah yang digunakan untuk menyatakan intensitas keadaan asam atau basa sesuatu larutan. Dalam penyediaan air, $\mathrm{pH}$ merupakan satu faktor yang harus dipertimbangkan mengingat bahwa derajat keasaman dari air akan sangat mempengaruhi aktivitas pengolahan yang akan dilakukan, misalnya dalam melakukan koagulasi kimiawi, desinfeksi, pelunakan air dan dalam pencegahan korosi (Suhartana 2006). Hasil pengamatan pH limbah cair hasil ekstraksi sagu sebelum dan sesudah difiltrasi terlihat pada Tabel 2.

Pengamatan menunjukkan bahwa derajat keasaman $(\mathrm{pH})$ limbah cair ekstraksi sagu sebelum perlakuan adalah 5,9 dan setelah diberi perlakuaan mengunakan media filtrasi $\mathrm{P}, \mathrm{S}, \mathrm{A}$ nilai $\mathrm{pH}$ meningkat berkisar 6,1-6,3. Media tanpa kombinasi yaitu media arang terlihat lebih efektif dibanding kedua media lainnya.

Limbah cair ekstraksi sagu yang
disaring dengan media kombinasi (perlakuan PS, PA dan SA) terlihat lebih efektif dalam meningkatkan $\mathrm{pH}$ limbah cair dibanding media tanpa kombinasi. Setelah filtrasi terlihat bahwa nilai $\mathrm{pH}$ mengalami peningkatan hingga berkisar
6,4-6,5. Peningkatan $\mathrm{pH}$ sesudah filtrasi diduga karena pengaruh penggunaan arang yang mampu mengadsorpsi padatan yang ada pada limbah, baik yang tersuspensi maupun yang terlarut serta senyawa organik yang dapat terurai pada limbah cair ekstraksi sagu. Peningkatan $\mathrm{pH}$ dikarenakan pada saat proses filtrasi, air yang mengalir melalui media filtrasi mengalami tumbukan atau benturan antar molekul air yang mengakibatkan terjadinya gelembung-gelembung udara (air melepaskan ion O) sehingga terjadi reaksi ion yang mengakibatkan air kelebihan ion $\mathrm{H}+$ sehingga $\mathrm{pH}$ air meningkat. 
Tabel 2. Hasil Pengukuran pH Limbah Cair Esktraksi Sagu

\begin{tabular}{cccc}
\hline \multirow{2}{*}{ Perlakuan } & \multicolumn{2}{c}{$\mathrm{pH}$} & \\
\cline { 2 - 3 } & $\begin{array}{c}\text { Sebelum } \\
\text { filtrasi }\end{array}$ & $\begin{array}{c}\text { Sesudah } \\
\text { filtrasi }\end{array}$ & St. Deviasi \\
\hline $\mathrm{P}$ & 5.9 & 6.2 & 0,001 \\
$\mathrm{~S}$ & 5.9 & 6.1 & 0,002 \\
$\mathrm{~A}$ & 5.9 & 6.3 & 0,001 \\
$\mathrm{PS}$ & 5.9 & 6.4 & 0,002 \\
$\mathrm{PA}$ & 5.9 & 6.5 & 0,072 \\
$\mathrm{SA}$ & 5.9 & 6.4 & 0,002 \\
\hline
\end{tabular}

\section{Bau}

Bau merupakan petunjuk adanya pembusukan air limbah. Penyebab adanya bau pada air limbah karena adanya bahan volatile, gas terlarut dan hasil samping dari pembusukan bahan organik. Hasil pengujian bau pada limbah cair ekstraksi sagu sebelum dan sesudah filtrasi tersaji pada Tabel 4.

Limbah cair ekstraksi sagu sebelum diberi perlakuan memiliki bau khas sagu dari proses penguraian senyawa organik. Namun setelah dilakukan filtrasi pada seluruh media filtrasi, maka limbah ekstrasi sagu menjadi tidak berbau. Hal ini menunjukkan bahwa media filtrasi berupa pasir, serabut dan arang tempurung kelapa dapat menghilangkan bau pada limbah cair ekstraksi sagu. Penghilangan bau diduga terjadi karena media filtrasi dapat mengurangi bahan padatan tersuspensi dan terlarut yang memberikan bau khas sagu. Bau yang dihasilkan oleh air limbah pada umumnya berupa gas yang dihasilkan dari peruraian zat organik yang terkandung dalam air limbah, seperti hidrogen sulfida (H2S). Bau air yang berubah berarti ada pencemaran. Bau disebabkan adanya bahan-bahan kimia yang terlarut atau tersuspensi dan terdapatnya ganggang, plankton, hewan air yang sudah mati atau membusuk (Santoso 2010).

Tabel 3. Hasil Pengujian Bau Limbah Cair Esktraksi Sagu

\begin{tabular}{ccc}
\hline \multirow{2}{*}{ Perlakuan } & \multicolumn{2}{c}{ Bau } \\
\cline { 2 - 3 } & Sebelum filtrasi & $\begin{array}{c}\text { Sesudah } \\
\text { filtrasi }\end{array}$ \\
\hline P & Bau khas sagu & Tidak berbau \\
S & Bau khas sagu & Tidak berbau \\
A & Bau khas sagu & Tidak berbau \\
PS & Bau khas sagu & Tidak berbau \\
PA & Bau khas sagu & Tidak berbau \\
SA & Bau khas sagu & Tidak berbau \\
\hline
\end{tabular}

\section{Warna}

Hasil pengujian warna pada limbah cair ekstraksi sagu sebelum dan sesudah filtrasi terlihat pada Tabel 4. Limbah cair yang dihasilkan dari proses ekstraksi pati sagu memiliki warna coklat kemerahan. Setelah difiltarasi pada media tunggal $(\mathrm{P}$,
S, dan A) terlihat bahwa warna yang dihasilkan relatif tidak berbeda dari warna sebelum difiltrasi. Namun pada perlakuan media filtrasi yang dikombinasikan (PS, PA, SA), warna limbah cair ekstraksi sagu menjadi kuning bening. 
Limbah cair ekstraksi sagu sebelum filtrasi berwarna coklat kemerahan diduga karena terjadi reaksi pencoklatan. Reaksi pencoklatan terjadi karena limbah cair ekstraksi sagu diduga masih mengandung senyawa fenolik yang teroksidasi. Menurut Winarno (1997), proses pencoklatan terjadi karena enzim fenol oksidase dan oksigen yang berhubungan dengan substrat senyawa fenolik. Perubahan warna sesudah filtrasi disebabkan karena menurunnya nilai zat padat terlarut dan zat padat tersuspensi yang menyebabkan limbah ekstraksi sagu menjadi lebih kuning bening. Arang yang berasal dari tempurung kelapa mempunyai kualitas sebagai adsorben yang baik hal ini ditandai dengan banyaknya pori-pori yang ada dalam arangnya. Keberadaan pori tersebut sangat bermanfaat untuk menyerap suspended solid dan senyawa organik yang terikut dalam air sehingga impuritas yang menyebabkan warna keruh dapat tertahan dalam arang kelapa (Ayatni et al. 2014).

Tabel 4. Hasil Pengujian Warna Limbah Cair Esktraksi Sagu

\begin{tabular}{ccc}
\hline \multirow{2}{*}{ Perlakuan } & \multicolumn{2}{c}{ Bau } \\
\cline { 2 - 3 } & Sebelum filtrasi & Sesudah \\
\hline P & Coklat kemerahan & Coklat kemerahan \\
S & Coklat kemerahan & Coklat kemerahan \\
A & Coklat kemerahan & Coklat kemerahan \\
PS & Coklat kemerahan & Kuning bening \\
PA & Coklat kemerahan & Kuning bening \\
SA & Coklat kemerahan & Kuning bening \\
\hline
\end{tabular}

\section{KESIMPULAN}

Berdasarkan hasil yang diperoleh dari penelitian ini, maka dapat disimpulkan bahwa media filtrasi pasir, serabut kelapa dan arang tempurung kelapa efektif dalam menurunkan nilai padatan tersuspensi dengan nilai efektifitas berturut-turut yaitu $11 \%, 8 \%$ dan $17 \%$. Efektifitas penurunan padatan terlarut yaitu $23 \%, 22 \%$ dan $24 \%$. pH meningkat menjadi 6,2, 6,1 dan 6,3 dan limbah cair esktrasi sagu menjadi tidak berbau. Namun jika dilakukan kombinasi media filtrasi, maka kualitas limbah cair ekstraksi sagu yang dihasilkan lebih baik. Hal ini terlihat dengan lebih tingginya efektifitas penurunan nilai padatan tersuspensi dan terlarut, warna limbah cair menjadi kuning bening dan tidak berbau.

\section{DAFTAR PUSTAKA}

Flach, M. 1983. Sago Palm Domestication, Explantation, and Production. FAG Plant Production and Protection Paper, 85.
Lakuy, H., \& Limbongan, J. 2003. Beberapa hasil kajian dan teknologi yang diperlukan untuk pengembangan sagu di Provinsi Papua . Seminar Nasional Sagu. Manado: Balai Penelitian Tanaman Kelapa dan Palma Lain .

Limbongan, J. 2007. Morfologi Beberapa Jenis Sagu Potensial di Papua. Jurnal Litbang Pertanian. 26 (1): 16-24.

Haryanto, B., \& Siswari, E. 2004. Pengaruh Usaha Pengolahan Sagu Skala Kecil Terhadap Baku Mutu Air Anak Sungai (Studi Kasus Industri Pengolahan Sagu di Kelurahan Cibuluh, Kota Bogor). J. Tek. Ling. P3TL-BPPT. 5 (3): 221-226.

Tumbel, N. 2014. Uji Kinerja Alat Pengolah Sagu Baruk (Arenga Microcarpa). Jurnal Penelitian Teknologi Industri. 6 (1): 43-54.

Kusuma, Y. L., Ahmad, A., \& Yelmida. 2012. Efisiensi Penyisihan Chemical Oxygen Demand (COD) Limbah 
Cair Pabrik Sagu Menggunakan Bioreaktor Hibrid Anaerob Pada Kondisi Tunak Dengan Variabel Laju Pembebanan Organik. Prosiding SNTK TOPI : 170-175.

Phang, S. M., Miah, M. S., Yeoh, B. G., \& Hashim, M. A. 2000. Spirulina Cultivation in Digested Sago Starch Factory Wastewater. Journal of Applied Phycology. 12: 395-400.

Ahmad, A. 1992. Kinerja Bioreaktor Unggun Fluidisasi Anaerobik Dua Tahap Dalam Mengolah Limbah Cair Industri Minyak Kelapa Sawit. $\square$ Laporan Magang: Institut Teknologi Bandung $\square$

Awg-Adeni, D. S., Abd-Aziz, S., Bujang, K., \& Hassan, M. A. 2010. Bioconversion of sago residue into value added products. African Journal of Biotechnology. 9 (14): 2016-2021.

BSN. 2005. SNI 06-6989.27-2005:Air dan air limbah - Bagian 27: Cara uji kadar padatan terlarut total secara gravimetri. Jakarta: Badan Standardisasi Nasional.

BSN. 2004. SNI 06-6989.3-2004: Air dan air limbah- Bagian 3: Cara uji padatan tersuspensi total (Total Suspended Solid, TSS) secara gravimetri. Jakarta: Badan Standardisasi Nasional.

BSN. 2004. SNI 06-6989.11-2004:Air dan air limbah - Bagian 11: Cara uji derajat keasaman $(\mathrm{pH})$ Bagian 11: Cara uji derajat keasaman $(\mathrm{pH})$ dengan menggunakan alat $\mathrm{pH}$ meter dengan menggunakan alat $\mathrm{pH}$ meter. Jakarta: Badan Standardisasi Nasional.

BSN. 2005. SNI 06-6989.24-2005: Air dan air limbah - Bagian 24 : Cara uji warna secara perbandingan visual. Jakarta: Badan Standarisasi Nasional.
Jenie, B., \& Rahayu, W. 1993. Penanganan limbah industri pangan. Yogyakarta: Kanisius.

Ayatni, F., Damajanti, N., \& Hamad, A. 2014. Pemanfaatan Arang Dari Limbah Tempurung Kelapa Sebagai Variasi Material Dalam Sand Filtration Untuk Penjernihan Air Sumur Di Kelurahan Tegalkamu lyan Cilacap. Seminar Nasional Hasil - Hasil Penelitian dan Pengabdian LPPM UMP : 113-118.

Utami, A. R. 2013. Pengolahan Limbah Cair Laundry Dengan Menggunakan Biosand Filter dan Activated Carbon. Jurnal Teknik Sipil Untan. 13 (1): 5971.

Siwardi, \& Putra, A. 2014. Pengaruh Konsentrasi Arang Ampas Tebu Terhadap Daya Serapnya Pada Limbah Cair Kelapa Sawit. Jurnal Fisika Unand. 3 (3): 128-134.

Susilawaty, A., Djaffar, M. H., \& Daud, A. 2007. Efektivitas sistem saringan multimedia dalam menurunkan TSS, BOD, NH3-N, PO4 dan total coliform pada limbah cair rumah tangga. Jurnal Sains dan Teknologi. 7 (1): 45-56.

Suhartana. 2006. Pemanfaatan Tempurung Kelapa Sebagai Bahan Baku Arang Aktif dan Aplikasinya Untuk Penjernihan Air Sumur di Desa Belor Kecamatan Ngaringan Kabupaten Grobogan. Berkala Fisika. 9 (3): 151-156.

Santoso, B. 2010. Proses Pengolahan Air Buangan Industri Tapioka. Jurnal Ilmiah Teknologi \& Rekayasa, 15 (3): 213-220.

Winarno, F. G. 1997. Kimia Pangan Gizi Edisi Kedua. Jakarta: PT. Gramedia Pustaka Utama. 